\title{
ON SOME DIATOMS FROM HIGH ALTITUDE GOKYO LAKE-III, SAGARMATHA NATIONAL PARK, NEPAL
}

\author{
S.K. Rai ${ }^{1}$, P.K. Misra ${ }^{2}$ and K. Maden ${ }^{3}$
}

\section{ABSRACT}

The present paper describes total 16 taxa of diatoms under 12 genera, belonging to 1 centric (Cyclotella antiqua W. Smith var. minor Suxena \& Venkateswarlu) and 15 pennate species from Gokyo lake- III, Sagarmatha National Park, Nepal. Of these, 6 were the new records for the country. The morphological descriptions, taxonomic accounts and distribution are described systematically with photographs.

Key Words: Bacillariophyceae, Gokyo lake, mount Everest, central Himalaya, Nepal

\section{INTRODUCTION}

Diatoms are the microscopic eukaryotic algae found in marine, freshwater habitats, moist soils, rock surfaces etc. They are mostly unicellular but some form chains or simple colonies and have a characteristic siliceous cell wall called 'frustule'. They have many importances in the field of ecology, environmental science, biogeochemistry, nano-biotechnology, bio-fuel, semiconductor industries etc. So, it is necessary to study the existing diatom flora of the nation and to develop the database and culture collection of this important group of micro-algae for further use in different biotechnological programs.

Diatom flora of Central Himalaya specially from the Himalaya region of Nepal has been studied by Hirano $(1955,1963,1969,1984)$, Suxena and Venkateswarlu (1968), Suxena et al. (1972), Subba Raju and Suxena (1979), Jüttner et al. (2000, 2003, 2004), Rothfritz et al. (1997), Cantonati et al. (2001), Simkhada (2006) and Subba et al. (2009). Among them, major and preliminary contribution was made by Hirano $(1955,1963,1984)$ recording a total 176 taxa of diatoms from Kungbachen, Mewa Valley, Wolangchung Gola of Eastern Nepal and Manang, Mustang, Kathmandu, Gorkha and Kaski of Central Nepal. Later on, Suxena and Venkateswarlu (1968) have also described 69 taxa of diatoms from Eastern Nepal especially from Bhote Koshi, Dudh Koshi, Imja and Lobuche rivers and Muzamba and Dudh Pokhari glacier lakes, all the localities lying between Mt. Everest and Mt. Cho Oyu at an altitude ranging from 3000-5200 $\mathrm{m}$. Further 3 species were also recorded from the same area by Subba Raju and Suxena (1979). Baral (1999) has published a checklist of algae of Nepal in which the total number of diatoms recorded from Nepal are only 195 . While studying the stream quality by using diatoms as bio-indicator, Jüttner et al. $(2000,2003,2004)$ have recognized a total 179 taxa including 7 new Gomphonema species viz. G. pararhombicum from Jumla, G. nepalense and G. saccatum from Taplejung, G. nediense and $G$. makaluense from Bhojpur and $G$. incognitum and G. sinestigma from Sankhuwasabha. Cantonati et al. (2001) have also reported 182 diatoms from High Mountain streams of Simikot-Rara lake, Jumla-Dunai, Manaslu circuit, Makalu and Kanchanjunga areas (all located above 3500 m). Recently, Subba et al. (2009) have reported a total 19 taxa of diatoms from stream and ponds of Upper Mustang Trans-Himalaya region. 
All these literature revealed that the exploration of diatoms in high altitude Himalaya region is sporadic and incomplete as diatoms from thousands of glacier lakes, ice fed streams and ponds of Nepal are still have to be explore. Thus, in the present study, an attempt has made to explore high altitude diatoms from Nepal Himalayas. Since there has been no report of diatoms from Gokyo lake hitherto, this is the preliminary attempt to explore these algae.

\section{STUDY AREA}

Gokyo wetland series (Latitude $27^{\circ} 57.02^{\prime} \mathrm{N}$ and Longitude $86^{\circ} 41.58^{\prime} \mathrm{E}$, Altitude $4700-5000 \mathrm{msl}$, Area 42.69 ha, Length $975 \mathrm{~m}$ ) is situated in Sagarmatha National Park, Solukhumbu District, east Nepal. This wetland series consists 6 main lakes; the largest is Thonak lake at $4834 \mathrm{~m}$ followed by Gokyo (DNPWC/WWF 2005). Gokyo-III (Latitude 27'56'59.4"N and Longitude $86^{\circ} 42^{\prime} 06^{\prime \prime} \mathrm{E}$, altitude $4780 \mathrm{msl}$ ) is a high altitude oligotrophic lake situated at the base of Mt. Everest in Khumjung Village Development Committee (Fig. 1). This area is a unique botanical site for study of various plant groups which lies on the head of Dudh Koshi River and is partially fed by Ngozumpa glacier. Gokyo is one of the popular tourist destinations as it visits by an average of over 7000 tournists per year (DNPWC/WWF 2005). The maximum precipitation (about $80 \%$ ) on this area falls in the monsoon season between June to September. Similarly, the minimum average temperature fall up to $-7.7^{\circ} \mathrm{C}$ in January and maximum average temperature rise up to $16.2^{\circ} \mathrm{C}$ in August.

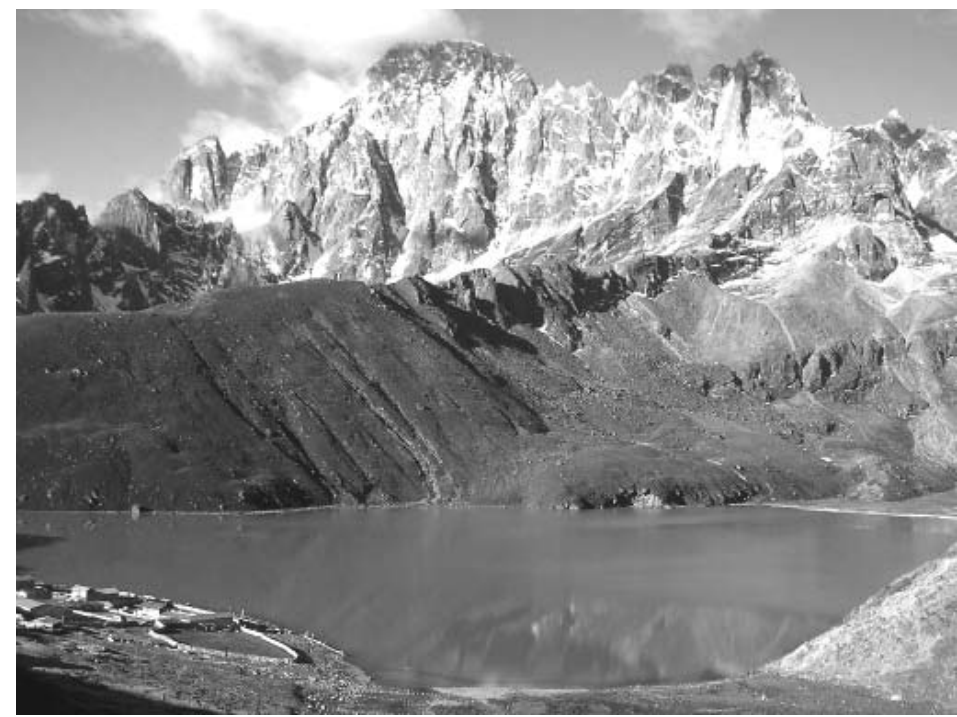

Fig. 1. Gokyo III lake (Photograph by Kamal Maden)

\section{MATERIALS AND METHODS}

Diatom samples were collected by one of the author (K. Maden) from Gokyo III lakes during "Botanical Expedition (Higher Group Plants) in the Sagarmatha National Park, east Nepal in 2004". This expedition was the first of three collaborative botanical collecting expeditions which 
form part of the training programme 'Building Capacity for Biodiversity Inventory and Conservation in Nepal', funded by the UK Government, Darwin Initiative Project (Rajbhandari et al. 2004).

Collections were made by scrubbing the pebbles with toothbrush and trapping with plankton net (mesh size 10 $\mu$ ) and immediately preserved in $4 \%$ formalin. In laboratory, samples were centrifuged, washed with hot saturated solution of chromic acid $\left(\mathrm{K}_{2} \mathrm{Cr}_{2} \mathrm{O}_{7}\right.$ in conc. $\left.\mathrm{H}_{2} \mathrm{SO}_{4}\right)$ and mounted by euparol. The slides thus prepared were observed and microphotographs of the frustules were taken using Nikon E-400 microscope with $\mathrm{H}$-III photomicrographic attachment. All their taxonomic treatments and identification were made by following Tiffany and Britton (1952), Hustedt (1961-1966), Prowse (1962), Metzeltin and Lange-Bertalot (1998), Gandhi (1999), You et al. (2009) and online available databases viz. WoRMS, ITIS, ADIAC and Algaebase. All the samples and slides have been deposited in the algal repository of Department of Botany, P.G. Campus, Biratnagar. Accession numbers of these collections are same as those of the collection numbers.

\section{RESULTS AND DISCUSSION}

A total,16 diatom taxa i.e., 1 centric (Cyclotella antiqua var. minor) and 15 pennate species, are recorded from Gokyo lakes, Sagarmatha National Park, Nepal. Among these, 6 taxa are found to be new to Nepal. They are Meridion circulare var. constricta, Achnanthes swazi, Didymosphenia geminata, Cymbella cornuta, C. cuspidata and Cymatopleura solea. Taxonomic account and distribution of all taxa are given below.

Phylum: Bacillariophyta

Class: Coscinodiscophyceae

Order: Thalassiosirales

Family: Stephanodiscaceae

Genus: Cyclotella (Kützing) Brébisson, 1838.

1. Cyclotella antiqua W. Smith var. minor Suxena and Venkateswarlu, 1968. [Suxena and Venkateswarlu 1968, pl. 1, f. 2] (Fig. 2)

Taxonomic description: Frustules small, $11 \mu \mathrm{m}$ in diameter; Cells drum-shaped with concentric ornamentation; Striae delicate, 14-19 in $10 \mu \mathrm{m}$, radially arranged towards the margin; Central area concave with three triangular depressions with apices towards the centre; Depressions are delicately punctate.

Collection number and Date: EN 260 (02-06-2004).

Distribution: Tributaries of Koshi river below Namche Bazar, 2900-4200 m, Solukhumbu (Suxena and Venkateswarlu 1968). Mongolia (Edlund et al. 2003) as Cyclotella antiqua.

Class: Fragilariophyceae

Sub Class: Fragilariophycidae

Order: Tabellariales

Family: Tabellariaceae 
Genus: Tabellaria Ehrenberg, 1839.

2. Tabellaria flocculosa (Roth) Kützing, 1844. [Tiffany and Britton, 1952, pl. 61, f. 694; Hustedt, 1959, f. 558; Foged, 1982, pl.1, f. 4\&10] (Figs. 3-4)

Basionym: Conferva flocculosa Roth, 1797.

Synonyms: Striatella flocculosa (Roth) Kütz.; Bacillaria flocculosa (Roth) Leiblein, 1827; Tabellaria fenestrata var. asterionelloides Grun. in Van Heurck., 1881; Tabellaria fenestrata var. geniculata A. Cleve, 1899; Tabellaria fenestrata var. intermedia Grun. in Van Heurck, 1881.

Taxonomic description: Valves short-elongated, 20-21 $\mu \mathrm{m}$ long, 8-9 $\mu \mathrm{m}$ broad, inflated markedly in the middle and slightly at the poles; Girdles 22-37 $\mu \mathrm{m}$ long, $23.5 \mu \mathrm{m}$ broad, united into zigzag chains, with numerous intercalary bands and septa; Striae finely punctate; Pseudoraphe narrow.

Collection number and Date: EN 260 (02-06-2004).

Distribution: Bhote Koshi river, 5250 m, Solukhumbu (Suxena \& Venkateswarlu, 1968); Sabha Pokhari lake, $4100 \mathrm{~m}$, Sankhuwa Sabha (Misra et al. 2009). China (Hu and Wei 2006), Iran (Sohrabipour \& Rabii, 1999).

Order: Fragilariales

Family: Fragilariaceae

Genus: Meridion C. Agardh, 1824.

3. Meridion circulare (Greville) C. Agardh var. constricta (Ralfs) Van Heurck, 1881. [Tiffany and Britton, 1952, pl. 61, f. 691] (Fig. 5)

Basionym: Meridion constrictum Ralfs.

Synonyms: M. circulare var. constrictum (Ralfs) Brun., 1880; M. constrictum Ralfs, 1843; $M$. circulare f. constricta (Ralfs) Cleve-Euler, 1932.

Taxonomic description: Valves and girdle both wedge-shaped; Valves 15-75 $\mu \mathrm{m}$ long, 3-7 $\mu \mathrm{m}$ broad, constricted at broader end, larger end broadly capitate; Girdles joined together by valve faces forming fan shaped or circular colony; Costae 3-5 in $10 \mu \mathrm{m}$; Striae fine, 15 in $10 \mu \mathrm{m}$.

Collection number and Date: EN 261 (02-06-2004).

Distribution: New record for Nepal. As M. circulare: A pond at Arughat Bazar, 770 m, Gorkha (Hirano, 1955); Pool and ditches at Bhaktapur (Shrestha and Manandhar 1983). China (Hu and Wei 2006).

Genus: Diatoma J.B.M. Bory de St-Vincent, 1824.

4. Diatoma hyemalis (Roth) Heiberg, 1863. [ADIAC, WoRMS. As D. hiemale- Tiffany \& Britton, 1952, pl. 61, f. 684; Benson \& Rushforth, 1975, pl. 12, f. 5] (Figs. 6-9)

Basionym: Conferva hyemalis Roth, 1800.

Synonym: Odontidium hyemale (Roth) Kützing, 1844. 
Taxonomic description: Valves linear-lanceolate, 30-74.5 $\mu \mathrm{m}$ long, 7-9.5 $\mu \mathrm{m}$ broad, slightly narrowed toward the rounded poles; Girdles $25-80 \mu \mathrm{m}$ long, $17-21.5 \mu \mathrm{m}$ broad, united into close chains with numerous intercalary bands; Costae prominent, 3-4 in $10 \mu \mathrm{m}$, irregular, coarse, extending the valve width, slightly obliquely placed; Striae parallel, very fine; Pseudoraphe narrow, linear-lanceolate.

Collection number and Date: EN 255 (01-06-2004).

Distribution: Himalaya streams of Nepal (Cantonati et al. 2001).

As D. hiemale (Lyngb.) Heib.: Sabha Pokhari lake, $4100 \mathrm{~m}$, Sankhuwa Sabha (Misra et al. 2009); Yara Khola, 3414 m, Upper Mustang (Subba et al. 2009).

As D. hiemale (Lyngb.) Heib. var. mesodon (Ehr.) Grun.: A stream west from Dudh Koshi river, $5250 \mathrm{~m}$, Solukhumbu (Suxena and Venkateswarlu, 1968); a stream at Wolang Chung Gola (Hirano, 1984); Cherse khola stream at Damku, 1690 m, Khotang (Misra et al. 2009).

Genus: Hannaea Patrick in Patrick \& Reimer 1966.

5. Hannaea arcus var. arcus (Ehr.) Patrick in Patrick \& Reimer, 1966. [WoRMS. As Ceratoneis arcus var. arcus: Hustedt, 1959, p. 179, f. 684 b; Suxena \& Venkateswarlu, 1968, p. 7, pl. 1, f. 4; Foged, 1982, p. 354, pl. 5, f. 1] (Fig. 10)

Taxonomic description: Valves lunate, arcuate, 55-60 $\mu \mathrm{m}$ long, 5-6 $\mu \mathrm{m}$ broad with rostratecapitate apices, a prominent tumescence in the middle at the concave side; Axial area narrow; Central area one sided, extend to the ventral margin; Pseudoraphe towards the concave margin; Striae fine, parallel, $15-17$ in $10 \mu \mathrm{m}$.

Collection number and Date: EN 260 (02-06-2004).

Distribution: As Ceratoneis arcus var. arcus: A stream below Namche Bazar, 2900-4200 m, Solukhumbu (Suxena and Venkateswarlu 1968); a stream at Kungbachen, 4150 m (Hirano 1984); Sapta Koshi river, 206 m, Koshi Tappu Wildlife Reserve, Sunsari (Rai 2006, Misra et al. 2009); Koshi Barrage, 152 m, Bhantabari, Sunsari (Rai 2006); Rawa khola river at Manglabare, 720 m, Khotang (Misra et al. 2009); Chhyo Pema pond, 3839 m, Upper Mustang (Subba et al. 2009).

Genus: Ulnaria Kützing, 1844.

6. Ulnaria ulna (Nitzsch) P. Compère, 2001. [ADIAC. As Synedra ulna: Gandhi, 1967, f. 63; Hadi et al., 1984, pl. 8, f. 146-149; Sinnu \& Squires, 1985, pl. 3, f. 22-23] (Fig. 11)

Basionym: Bacillaria ulna Nitzsch, 1827.

Synonyms: Synedra ulna (Nitzsch) Ehrenberg, 1832; Exilaria ulna (Harvey) Jenner, 1845; Fragilaria ulna (Nitzsch) Lange-Bertalot, 1980.

Taxonomic description: Valves solitary, 55-235 $\mu \mathrm{m}$ long, 5-9 $\mu \mathrm{m}$ broad, linear to linear lanceolate, gradually attenuated towards the rostrate or broadly rounded ends; Central area quadrangular having small lineate striae on both margins; Striae coarse, 9-11 in $10 \mu \mathrm{m}$, lineate, transverse and parallel.

Collection number and Date: EN 257 (01-06-2004). 
Distribution: As Synedra ulna: Taudaha, 1350 m, Kathmandu (Hickel 1973); Punyamati river, Panauti, Kavrepalanchowk (Aryal and Lacoul 1996); Gajurmukhi, Ilam (Rai et al. 2008); Saptakoshi river at Koshi Tappu Wildlife Reserve, 720 m, Sunsari; Itahari roadside ditches, 120 m, Sunsari; Triyuga river at Gaighat, 152 m, Udayapur (Misra et al. 2009); Yamda Khola, 3889 m, Upper Mustang (Subba et al. 2009).

As Fragilaria ulna: Kathmandu, Likhu Khola and Arun valley (Jüttner et al.1996, Cantonati et al. 2001).

As Synedra ulna: China (Hu and Wei 2006); Iran (Ramzannejad Ghadi 2008).

As Fragilaria ulna- Turkey (Soylu and Gönülol 2005).

Class: Bacillariophyceae

Sub Class: Eunotiophycidae

Order: Eunotiales

Family: Eunotiaceae

Genus: Eunotia Ehrenberg, 1837.

7. Eunotia naegelii Migula, 1907. [ADIAC. As E. alpine: Gandhi, 1960, pl. 1, f. 19; Prasad \& Srivastava, 1992, pl. 26, f. 7] (Fig. 12)

Synonym: Eunotia alpina (Naeg. ex Kütz.)

Taxonomic description: Valves slightly arcuate, $27 \mu \mathrm{m}$ long, $4.2 \mu \mathrm{m}$ broad, linear, gradually tapering from the middle towards the rounded ends, dorsal margin convex, slightly recurved at the apices, ventral margin concave; Polar nodules distinct; Raphe not well developed; Striae fine, 19-20 in $10 \mu \mathrm{m}$, lineate, parallel.

Collection number and Date: EN 260 (02-06-2004).

Distribution: As E. alpina: Sabha Pokhari lake, 4100 m, Sankhuwa Sabha (Misra et al., 2009).

8. Eunotia polydentula Brun. var. perpusilla Grun. (Hustedt), 1959. [Hustedt, 1959, f. 759ae] (Fig. 13)

Taxonomic description: Valves arcuate, $20 \mu \mathrm{m}$ long, 3-3.5 $\mu \mathrm{m}$ broad, dorsal margin convex with four hemps, middle two slightly small and close, ventral margin concave, slightly swollen near the poles opposite to lateral hemps; Ends broadly rounded; Terminal nodules and raphe small but distinct at the apices near ventral margin; Striae fine,18-25 in $10 \mu \mathrm{m}$, lineate.

Collection number and Date: EN 259 (01-06-2004).

Distribution: Sabha Pokhari lake, 4100 m, Sankhuwa Sabha (Misra et al. 2009).

Sub Class: Bacillariophycidae

Order: Achnanthales

Family: Achnanthaceae

Genus: Achnanthes Bory de Saint-Vincent, 1822. 
9. Achnanthes swazi Cholnoky [Carter, 1970, pl. 1, f. 33-34] (Fig. 14)

Taxonomic description: Valves small, 33-37 $\mu \mathrm{m}$ long, 12-15.3 $\mu \mathrm{m}$ broad, broadly elliptic or somewhat quadrate with broadly produced rostrate ends; Raphe thin, straight; Axial area narrow, linear; Central area broad; Striae lineate, radial.

Collection number and Date: EN 261 (02-06-2004).

Distribution: New record for Nepal.

Order: Naviculales

Sub Order: Sellaphorineae

Family: Pinnulariaceae

Genus: Pinnularia Ehrenberg, 1843.

10. Pinnularia conica Gandhi, 1956. [Gandhi, 1956-1957, f. 9-10; Gandhi, 1960, pl. 2, f. 5758] (Fig. 15)

Taxonomic description: Valves linear-lanceolate, $65 \mu \mathrm{m}$ long, $10.5 \mu \mathrm{m}$ broad with slightly convex to rarely subparallel sides; Apices slightly constricted, produced, slightly capitatecuneate; Raphe thin, more or less straight with distinct central nodules and curved terminal fissures: Axial area narrow, linear; Central area large, reaching the sides; Striae coarce, 10 in $10 \mu \mathrm{m}$, strongly radial at the middle, convergent towards apices.

Collection number and Date: EN 260 (02-06-2004).

Distribution: Mai Pokhari, 2150 m, llam (Rai, 2005).

11. Pinnularia viridis (Nitzsch) Ehrenberg, 1843. [Tiffany \& Britton, 1952, pl. 70, f. 809; Prasad \& Srivastava, 1992, pl. 30, f. 6] (Fig. 16)

Basionym: Bacillaria viridis Nitzsch, 1817.

Synonym: Frustulia viridis (Nitzsch) Kütz., 1833; Navicula viridis (Nitzsch) Ehr., 1835; Schizonema viride (Nitzsch) Kuntze, 1898; Pinnularia semicruciata (Ehr.) Cleve

Taxonomic description: Valves solitary, linear to elliptic-linear, 44-125 $\mu \mathrm{m}$ long, 8-25 $\mu \mathrm{m}$ broad, almost parallel or slightly convex sides and broadly rounded ends; Axial area less than $1 / 4$ of cell diameter, narrow near the poles, widened centrally; Central area round or elliptical; Raphe thick, undulate with a one-sided central pore; Transverse striae coarse, lineate, 6-9 in $10 \mu \mathrm{m}$, slightly radial medianly and convergent polarly, crossed by a wide longitudinal band.

Collection number and Date: EN 261 (02-06-2004).

Distribution: Manang bhot base camp, $3500 \mathrm{~m}$, Manang and Pond at Tukucha moor, 2600 m, Mustang (Hirano 1955); Bhaktapur (Shrestha and Manandhar, 1983); Garphu Khola, 3891 m, Upper Mustang (Subba et al. 2009). China (Hu and Wei 2006)

Order: Cymbellales

Family: Gomphonemataceae

Genus: Didymosphenia M. Schmidt, 1899. 
12. Didymosphenia geminata (Lyngbye) M. Schmidt, 1899. [Tiffany \& Britton, 1952, pl. 73, f. 850] (Fig. 17)

Basionym: Echinella geminata Lyngbye, 1819.

Synonyms: Gomphonema geminatum (Lyngbye) C.A. Agardh, 1824; G. vulgare Brébisson, 1838.

Taxonomic description: Valves bi-constricted, 60-125 $\mu \mathrm{m}$ long, 23-37 $\mu \mathrm{m}$ broad, broadly rounded sub-truncate apices, the apex is larger than the base; Axial area linear; Central area rounded, 2-4 stigmata in a longitudinal row; Raphe terminally with dorsal hooks; Transverse striae radial, 8-10 in $10 \mu \mathrm{m}$, medianly long and short striae alternately.

Collection number and Date: EN 260 (02-06-2004).

Distribution: New record for Nepal. China (Kilroy, 2004; Hu \& Wei, 2006), Iran (Jamaloo et al., 2006; Ramzannejad Ghadi, 2008)

Family: Cymbellaceae

Genus: Cymbella C.A. Agardh, 1830.

13. Cymbella cistula (Hempr and Ehr.) Kirchn, 1878. [Tiffany \& Britton, 1952, pl. 74, f. 861; Foged, 1982, pl. 8, f. 13; Sinnu \& Squires, 1985, pl. 13, f. 115-117] (Fig. 18)

Synonym: Cocconema cistula (Ehr.) Ehr., 1831.

Taxonomic description: Valves naviculoid, asymmetric, 35-100 $\mu \mathrm{m}$ long, 13-31 $\mu \mathrm{m}$ broad, dorsal side convex, ventral side concave with a median expansion and bluntly rounded ends; Raphe broad, excentric; Axial area narrow, widened slightly at middle; Transverse striae 6-9 in $10 \mu \mathrm{m}$, radial with isolated 2-4 stigmata at the ends of the middle ventral striae; Punctae $18-22$ in $10 \mu \mathrm{m}$.

Collection number and Date: EN 257 (01-06-2004).

Distribution: Dudh Koshi river on the way from Dudh Pokhari to Dole village, $4790 \mathrm{~m}$, Solukhumbu (Suxena and Venkateswarlu 1968); A stream at Kungbachen, 4150 m (Hirano, 1984); Mai Pokhari, 2150 m, Ilam (Rai 2005); Gajurmukhi, llam (Rai et al. 2008); Bhalle Khola, 4688 m, Upper Mustang (Subba et al. 2009). China (Hu and Wei 2006), Iran (Afsharzadeh et al. 2003; Ramzannejad Ghadi 2008), Pakistan (Mehwish and Aliya 2005), Turkey (Soylu and Gönülol 2005)

14. Cymbella cornuta (Ehr.) R. Ross, 1950. [Hartley, 1986] (Fig. 19)

Synonyms: Cocconema cornutum Ehr., 1839; Cymbella boeckii (Grun. in A. Shmidt)

Taxonomic description: Valves naviculoid, asymmetric, $109 \mu \mathrm{m}$ long, $23 \mu \mathrm{m}$ broad, dorsal side convex, ventral side concave with a median expansion; Raphe narrow, excentric, medianly curved; Axial area narrow, slightly expanded at middle, no isolated dots; Transverse striae radial, 8-15 in $10 \mu \mathrm{m}$; Puncta 14-18 in $10 \mu \mathrm{m}$.

Collection number and Date: EN 256 (01-06-2004).

Distribution: New record for Nepal. 
15. Cymbella cuspidata Kützing, 1844. [Tiffany \& Britton, 1952, pl. 74, f. 863] (Fig. 20)

Taxonomic description: Valves broad, linear-lanceolate, asymmetric, 32-90 $\mu \mathrm{m}$ long, 12-29 $\mu \mathrm{m}$ broad, constricted below the capitate ends; Raphe excentric, slightly straight; Axial area narrow; Central area large, circular; Transverse striae radial, 8-14 in $10 \mu \mathrm{m}$.

Collection number and Date: EN 258 (01-06-2004).

Distribution: New record for Nepal. China (Hu and Wei 2006),

Order: Surirellales

Family: Surirellaceae

Genus: Cymatopleura W. Smith, 1851.

16. Cymatopleura solea (Bréb.) W. Smith, 1851. [Foged, 1980, pl.15, f. 2; Sinnu \& Squires, 1985, pl. 20, f. 186] (Fig. 21)

Basionym: Cymbella solea Bréb., 1835.

Synonyms: Surirella solea (Bréb.) Bréb., 1838; Cymatopleura solea var. regula (Ehr.) Grun., 1862.

Taxonomic description: Valves large, broadly linear, 70-140 $\mu \mathrm{m}$ long, 10-28 $\mu \mathrm{m}$ broad, wide constriction at the middle with attenuated, cuneate ends; Costae broad, 6-9 in $10 \mu \mathrm{m}$, short at the periphery of the valve; Transverse striae fine, perpendicular to the margin.

Collection number and Date: EN 260 (02-06-2004).

Distribution: New record for Nepal. China (Hu and Wei 2006), Iran (Afsharzadeh et al. 2003, Jamaloo et al. 2006)

The diatom flora of Himalaya region is rich and diverse (Misra et al. 2009). Suxena and Venkateswarlu (1968), Hirano (1984) and Misra et al. (2009) have also studied the diatom flora of eastern Nepal Himalaya and recorded many species which are also found in the present study. Most of the diatoms were found to be attached on the pebbles near the edge of the pond. Pennate forms were common than the centric as usual. Among the 16 diatom taxa, Meridion circulare var. constricta, Tabellaria flocculosa, Diatoma hyemalis, Hannaea arcus var. arcus and Cymbella cistula were common whereas UInaria ulna, Eunotia polydentula var. perpusilla, Achnanthes swazi, Didymosphenia geminata, Cymbella cornuta, Cymbella cuspidata and Cymatopleura solea were rare. The dominant species was Tabellaria flocculosa which occurred in almost all the collected samples.

It is not oppugn that the taxonomic exploration of organism is most essential for their proper documentation and conservation strategy. Furthermore, diatoms are important to measure the water quality of stream and ponds in hilly region and may act as a major bio-indicator for the climate change in the whole Himalaya region. Thus, further extensive exploration of diatoms throughout the Himalayan range of Nepal, periodically as well as seasonally and their relationship with water chemistry are essential and to be carried out in the future. 


\section{ACKNOWLEDGEMENTS}

We are thankful to the Head of Botany Department, University of Lucknow and the Director, Central Drug Research Institute, Lucknow for the laboratory and photomicrography facilities, respectively. The first author is thankful to the University Grant Commission, Nepal for the financial assistance. Similarly, the third author is thankful to Darwin Initiative Project, UK Government for the opportunity to go field trip in Sagarmatha National Park as a Darwin Scholar.

\section{REFERENCES}

ADIAC (Automatic Diatom Identification and Classification). Online database accessed on 2010/04/12.

Afsharzadeh, S., T. Nejadsatari, M.R. Rahiminejad and M. Ebrahimnejad, 2003. Study of algal flora in Zayanderood river. Iranian Journal of Biology, 14:32-45.

Algaebase. Available online at http://www.algaebase.org

Aryal, S. and P. Lacoul,1996. Water quality and diversity of diatoms in Punyamati river, Nepal. Ecoprint, 3(1):45-49.

Baral, S.R.,1999. Algae of Nepal. In Majupuria, T.C. and R. Kumar (eds) Nepal Nature's Paradise, Gwalior, India, pp 655-681.

Benson, C.E. and S.R. Rushforth,1975. The algal flora of Huntington Canyon, Utah, USA. Bibliotheca Phycologica, 18:1-177.

Cantonati, M., G. Corradini, I. Jüttner, and E.J. Cox, 2001. Diatom assemblages in high mountain streams of the Alps and the Himalaya. Nova Hedwigia, 123:37-61.

Carter, J.R.,1970. Diatom from Andorra. Beih. Nova Hedwigia, Diatomaceae II 31:605-632.

DNPWC/WWF, 2005. High altitude wetlands of Nepal, Factsheet. Department of National Parks and Wildlife Conservation, Babarmahal and WWF Nepal Program, Baluwatar, Kathmandu, Nepal.

Edlund, M.B., R.M. Willians and N. Soninkhishig, 2003. The planktonic diatom diversity of ancient lake Hovsgol, Mongolia. Phycologia, 42:232-260.

Foged, N.,1980. Diatoms in Egypt. Nova Hedwigia, 33(1-4):629-675-707.

Foged, N.,1982. Diatoms in Human Tissue. Nova Hedwigia, 36(2-4): 345-379.

Gandhi, H.P.,1956-1957. A contribution to our knowledge of the diatom genus Pinnularia. J. Bomb. Nat. Hist. Soc., 54:845-852.

Gandhi, H.P.,1960. Fresh water diatomflora of the Panhalgarh hillfort in the Kolhapur district. Hydrobiol, 14(2):93-129.

Gandhi, H.P.,1967. Notes on the diatomaceae from Ahamedabad and its environs- VI. On some diatom from fountain reservoir of Seth Sarabhai's Garden. Hydrobiol., 30(2):248-272.

Gandhi, H.P.,1999. Fresh water diatom of cental Gujrat. Deharadun, India, 324 p.

Hadi, R.A.M., A.A. Al-saboonchi and A.K.Y. Haroon,1984. Diatoms of the Shatt al-Arab river, 
Iraq. Nova Hedwigia, 39(3-4): 513-544-557.

Hartley, B.,1986. A check-list of the freshwater, brackish and marine diatoms of the British Isles and adjoining coastal water. J. Mar. Biol. Ass., U.K. 66: 531-610.

Hickel, B.,1973. Phytoplanktons in two ponds in Kathmandu Valley, Nepal. Int. Rev. ges Hydrobiol., 58(6):835-842.

Hirano, M.,1955. Fresh water algae. In Kihara, H. (ed) Fauna and flora of Nepal Himalaya. Fauna and Flora Research Society, Kyoto University, Kyoto, Japan. pp 5-42.

Hirano, M.,1963. Fresh water algae from the Nepal Himalaya, collected by a member of the Japanese Climbing Expedition. Contr. Biol. Lab., Kyoto Univ., Japan, 16:1-23.

Hirano, M.,1969. Fresh water algae from Langtang Himal, Nepal Himalaya. Contr. Biol. Lab., Kyoto Univ., Japan, 22:1-42.

Hirano, M.,1984. Fresh water algae from east Nepal. Study reported of Baika Junior College 32:197-215.

$\mathrm{Hu}, \mathrm{H}$. and Y. Wei, 2006. The fresh water algae of China. Systematics, taxonomy and ecology. China: www.sciencep.com, pp 1-1023.

Hustedt, F.,1959. Die Kieselalgen Deutschlands, Österreichs Und der Schweiz, Vol. 2. Koeltz Scientific Books, USA, $845 \mathrm{p}$ (in German).

Hustedt, F.,1961-1966. Die Kieselalgen Deutschlands, Österreichs und der Schweiz unter Berücksichtigung der übrigen Länder Europas sowie der angrenzenden Meeresgebiete, Part 3, Vol. VII. B. Singh and M.P. Singh, Dehradun, India, 816 p (in German).

ITIS (Integrated Taxonomic Information System). Online database at $h t t p: / / w w w . i t i s . g o v$, accessed on 2010/05/19.

Jamaloo, F., F. Falahian, T. Nejadsatarai and A. Majd, 2006. Study of diatoms flora in Jajrood river. Science and Technology of Environment, 26:98-112.

Jüttner, I., E. Reichardt and E.J. Cox, 2004. Taxonomy and ecology of some new Gomphonema species common in Himalayan streams. Diatom Research, 19(2):235-264.

Jüttner, I., E.J. Cox and S.J. Ormerod, 2000. New or poorly known diatoms from Himalayan streams. Diatom Research, 15(2):237-262.

Jüttner, I., H. Rothfritz and S.J. Ormerod,1996. Diatoms as indicators of river quality in the Nepalese Middle hills with consideration of the effects of habitat-specific sampling. Freshwater Biology, 36:475-486.

Jüttner, I., S. Sharma, B.M. Dahal, S.J. Ormerod, P.J. Chimonides and E.J. Cox, 2003. Diatoms as indicators of stream quality in the Kathmandu valley and Middle hills of Nepal and India. Freshwater Biology, 48:2065-2084.

Kilroy, C., 2004. A new alien diatom, Didymosphenia geminata (Lyngbye) Schmidt: its biology, distribution, effects and potential risks for New Zealand fresh waters. Christchurch National Institute of Water and Atmospheric Research Ltd. Report No.: NIWA Client Report: CHC 2004- 
128, pp 1-40.

Mehwish, H. and R. Aliya, 2005. Occurrence of freshwater algae at different localities of Karanchi University. Int. J. Phycol. Phycochem., 1:117-124.

Metzeltin, D. and H. Lange-Bertalot,1998. Tropical diatoms of south America 1:700 predominately rarely known or new taxa representative of the neotropical flora. Vol.5. Lubrecht and Cramer Ltd., NY, USA, 695 p.

Misra, P.K., S.K. Rai and M.N. Srivastava, 2009. Fresh water diatoms from eastern Nepal-I. Indian Hydrobiology, 12(1):95-104.

Prasad, B.N. and M.N. Srivastava,1992. Fresh water algal flora of Andaman and Nicobar Islands, Vol. I, B. Singh and M.P. Singh Publ., Dehradun, India, 369 p.

Prowse, G.A.,1962. Diatoms of Malayan fresh waters. The garden's bull., Singapore. 19(1): $1-105$.

Rai, S.K., 2005. Preliminary report of diatoms from Maipokhari lake, Ilam, Nepal. Our Nature 3(1): 26-30.

Rai, S.K., 2006. Taxonomic studies on some freshwater diatoms from the eastern Terai region, Nepal. Our Nature, 4:10-19.

Rai, S.K., B.R. Subba and K.P. Limbu, 2008. Fresh water algae from running streams of Gajurmukhi VDC, Ilam, Nepal. Our Nature, 6:80-81.

Rajbhandari, K.R., R.K. Upreti, V.K. Manandhar, K. Maden and B. Adhikari, 2004. Botanical expedition in the Sagarmatha National Park, east Nepal in 2004. Plant Resources (An Occasional Publication). Ministry of Forests and Soil Conservation, Department of Plant Resources.

Rothfritz, H., I. Jüttner, A.M. Suren and S.J. Ormerod,1997. Epiphytic and epilithic diatom communities along environmental gradients in the Nepalese Himalaya: implications for the assessment of biodiversity and water quality. Arch. für Hydrobiol., 138:465-482.

Shrestha, B. and J.D. Manandhar,1983. Contribution to the algal flora of Kathmandu Valley. J. Inst. Sci. Techn. (Nepal) 6:1-6.

Simkhada, B., 2006. Diatoms as indicators of environmental change in lakes and ponds of the lowlands, middle hills and high Himalaya of Nepal. Ph.D. Thesis, Faculty of Biology, University of Bielefeld, Britain.

Sinnu, N.A. and L.E. Squires,1985. Diatoms of the Damour river, Lebanon. Nova Hedwigia, 41(1-4):291-320-341.

Sohrabipour, J. and R. Rabii,1999. A list of marine algae of seashores of Persian gulf and Oman sea in the Hormozgan province. Iran. Journ. Bot., 8(1):131-162.

Soylu, E.N. and A. Gönülol, 2005. Epipelic algal flora and seasonal variations of the river Yesilirmak, Amasya, Turkey. Cryptogamie, 26:373-385.

Subba Raju, N. and M.R. Suxena,1979. Algae and Testacea of the Cho Oyu (Himalayas) Expedition-II; Cyanophyta, Chlorophyta, Euglenophyta, Chrysophyta and Testacea. Hydro- 
biologia, 67(2):141-160.

Subba, B.R., M.R. Pandey, K.P. Limbu and S.K. Rai, 2009. On some diatoms from Upper Mustang Trans-Himalaya region, Nepal. Our Nature, 7(1):243-247.

Suxena, M.R. and V. Venkateswarlu,1968. Algae of the Cho Oyu (E. Himalaya) Expedition-I. Bacillariophyceae. Hydrobiologia, 32:1-26.

Suxena, M.R., V. Venkateswarlu and V.S. Rao,1972. Algae of the Cho Oyo (E. Himalaya) Expedition-II. Bacillariophyceae-II. Nova Hedwigia, 23(2-3):415-426.

T.C. Watter and M.J. Costello (eds), Online at $h t t p: / / w w w . m a r i n e s p e c i e s . o r g$, accessed on 2010/03/06.

Tiffany, L.H. and M.E. Britton, 1952. The algae of Illinois. Hafner publishing Co., New York. 407 p. WoRMS (World Register of Marine Species). Online at http://www.marinespecies.org/aphia, assessed on 2010-05-10.

You, Q., Y. Liu, Y. Wang and Q. Wang, 2009. Taxonomy and distribution of diatoms in the genera Epithemia and Rhopalodia from the Xinjiang Uygur Autonomous Region, China. Nova Hedwigia, 89(3-4):397-430.

\section{AUTHOR'S ADDRESS}

\section{Shiva Kumar Rai ${ }^{1}$}

Department of Botany, Post Graduate Campus, Tribhuvan University, Biratnagar, Nepal (email: shivarai2003@yahoo.com)

\section{Pradeep Kumar Misra ${ }^{2}$}

Phycology Research Laboratory, Department of Botany, University of Lucknow-226007, India Kamal Maden ${ }^{3}$

Freelance Researcher, Kathmandu, Nepal 


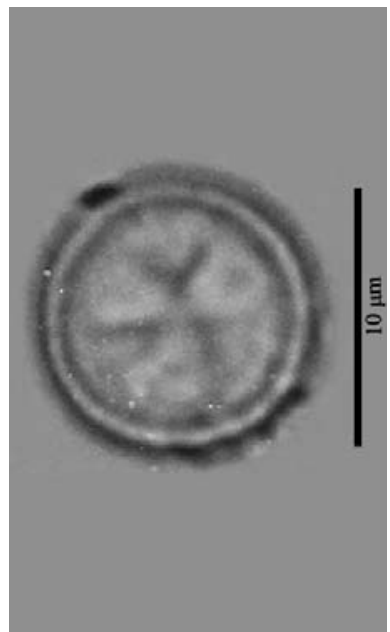

Fig. 2. Cyclotella antiqua var. minor

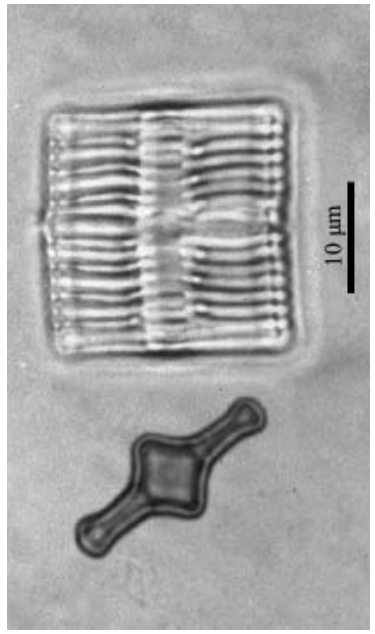

Fig. 4. Tabellaria flocculosa

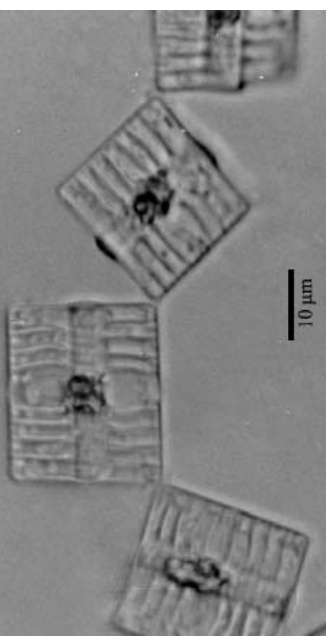

Fig. 3. Tabellaria flocculosa

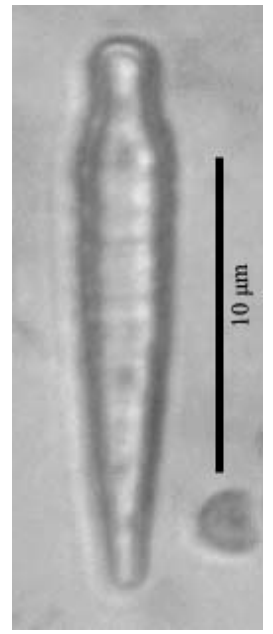

Fig. 5. Meridion circulare var. constricta 


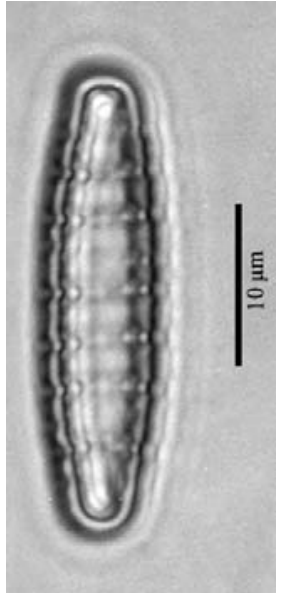

Fig. 6. Diatoma hyemalis (Girdle view)

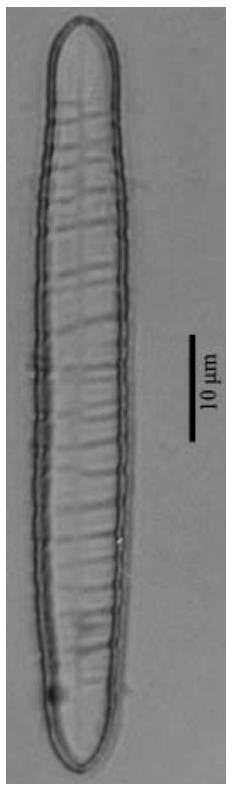

Fig. 8. Diatoma hyemalis (Girdle view)

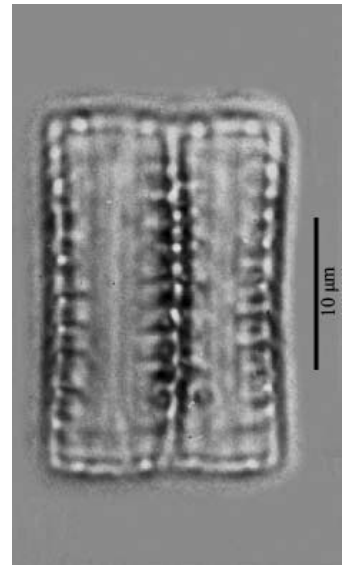

Fig. 7. Diatoma hyemalis (Valve view)

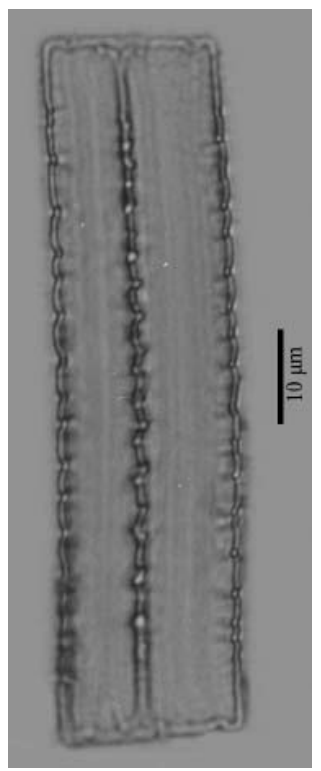

Fig. 9. Diatoma hyemalis (Valve view) 


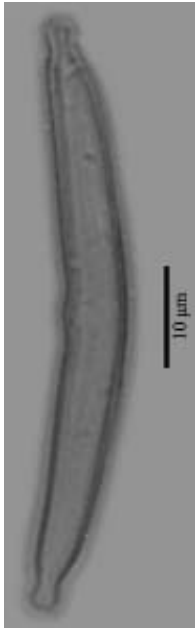

Fig. 10. Hannaea arcus var. arcus

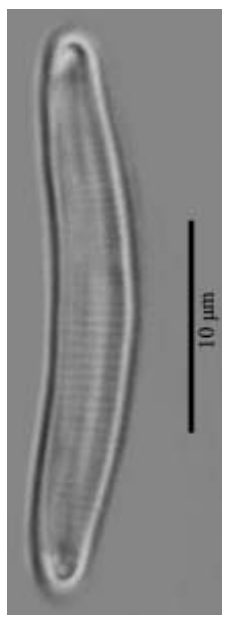

Fig. 12. Eunotia naegelii

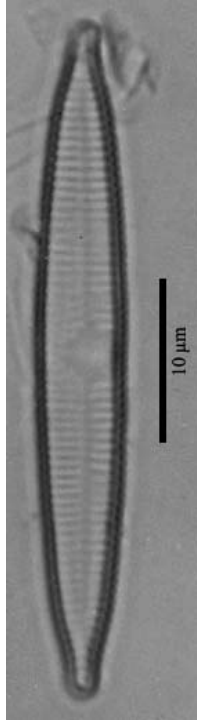

Fig. 11. Ulnaria ulna

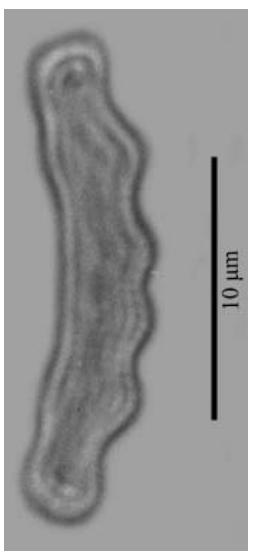

Fig. 13. Eunotia polydentula var. perpusilla 


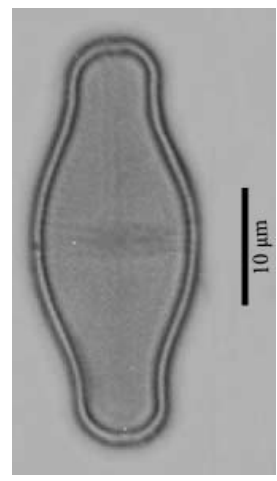

Fig. 14. Achnanthes swazi

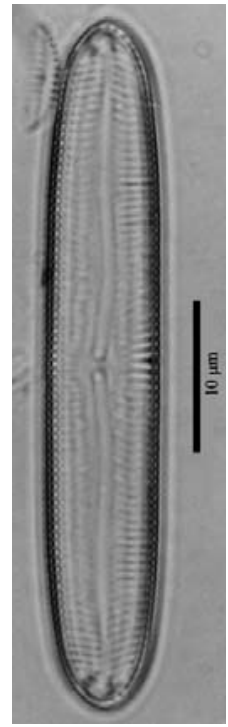

Fig. 16. Pinnularia viridis

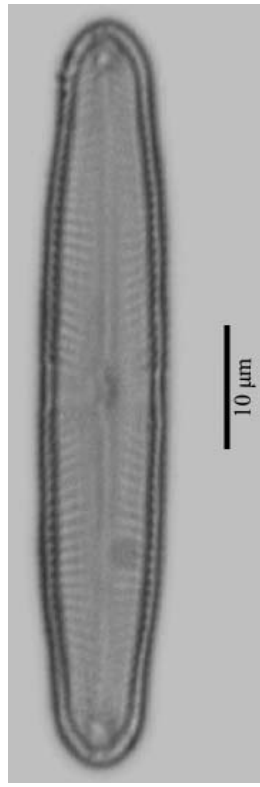

Fig. 15. Pinnularia conica

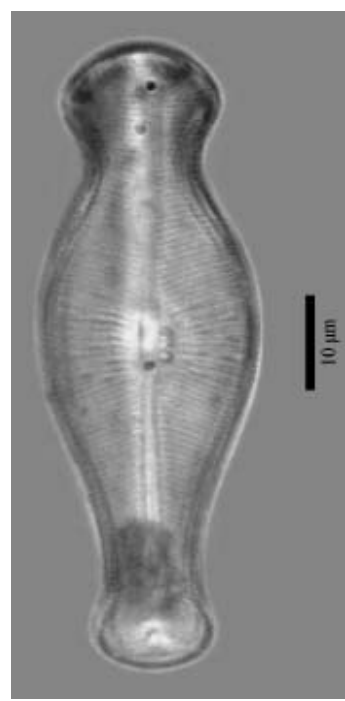

Fig. 17. Didymosphenia geminata 


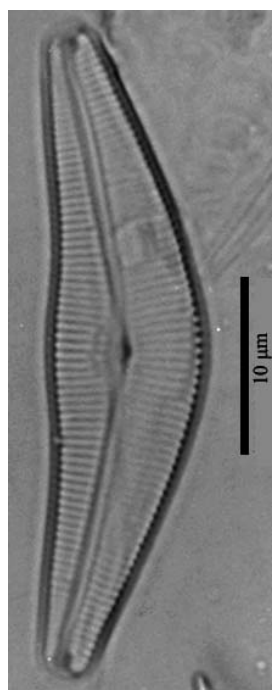

Fig. 18. Cymbella cistula

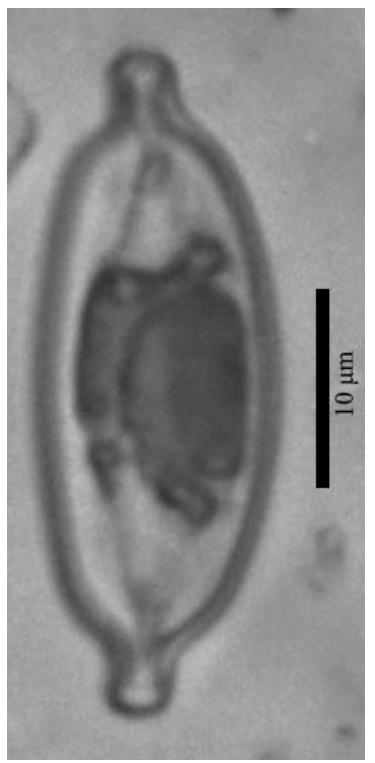

Fig. 20. Cymbella cuspidata

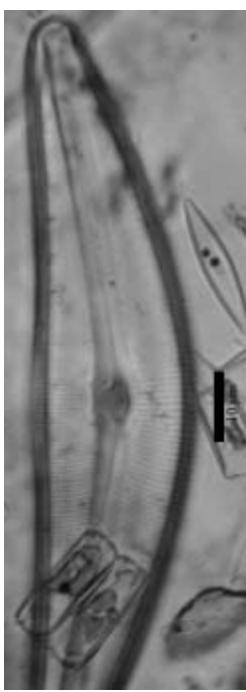

Fig. 19. Cymbella cornuta

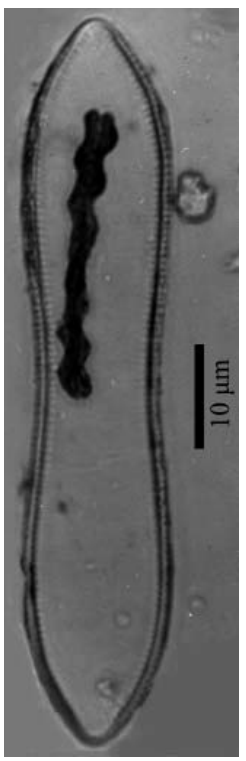

Fig. 21. Cymatopleura solea 